\title{
THE RELATIONSHIP BETWEEN THE BOARDS CHARACTERISTICS AND THE RISK MANAGEMENT OF THE ROMANIAN BANKING SECTOR
}

\author{
Mariana BUNEA ${ }^{1 *}$, Vasile DINU ${ }^{2,3}$ \\ ${ }^{1}$ Department of Accounting and Audit, Faculty of Accounting and Management Information Systems, \\ Bucharest University of Economic Studies, Bucharest, Romania \\ ${ }^{2}$ Department of Business, Consumer Sciences, and Quality Management, \\ Faculty of Business and Tourism, Bucharest University of Economic Studies, Romania \\ ${ }^{3}$ Academy of Romanian Scientists and The Union of Professional Journalists from Romania, Romania
}

Received 19 March 2020; accepted 04 May 2020

\begin{abstract}
The main objective of this research is to analyse the relationship between the board of director' structure of the banks from the Romanian bank sector, the capital demands and the risk management in what concerns these relationships. Regarding the structure of the board of directors, their size is under the loop, alongside with the education of its members, the gender diversity and the members nationality. The indicators concerning the capital demand that are subject of this research are the solvency and the level of the total own funds of the banks and the ones expressing the risk management are represented by the total exposure of weighted assets according to the risk (RWA), the credit risk exposure, the market risk and the operational risk. The authors have tried to answer the question: Is there or is not a direct relationship between the top of the range board of directors structure and the risk management for the banks from the Romanian bank sector? To answer this question, the used methodology is mainly quantitatively, having as core the deductive statistical analysis, testing and identifying connections from the effect and cause category, considering also the significance level.
\end{abstract}

Keywords: supervision, risk management, weighted assets according to the risk, corporate governance, financial performance, banking system, gender diversity, size, board.

JEL Classification: M40, G20, G30.

\section{Introduction}

This study aims at analyzing the influence that the structure of the board of director has, as an element of corporate governance, upon the capital demands and the risk management in the context of the Romanian banking system. Thus, the article is presenting and developing further a series of relevant results of previous studies taking into consideration three main

*Corresponding author. E-mail: maribunea@yahoo.com

This is an Open Access article distributed under the terms of the Creative Commons Attribution License (http://creativecommons. org/licenses/by/4.0/), which permits unrestricted use, distribution, and reproduction in any medium, provided the original author and source are credited. 
domains of research: corporate governance, banking performance and banking risk management.

Considering the recent international financial crisis, the corporate governance deficiencies of the financial institutions were subject of many political debates becoming the centre of some thorough academically research (e.g., Pathan \& Skully, 2010; Aebi et al., 2012; Liang et al., 2013; Pathan \& Faff, 2013; Stulz, 2016; Abou-El-Sood, 2017; Farag \& Mallin, 2017).

One of the main findings about what caused the financial crisis is that the banking societies have taken a range of excessive risks, fact that determined many failures in the banking sector. Among the key factors that have contributed to these failures, there were the inadequate mechanisms of internal management of the risks Bebchuk and Spamann (2010), Guerrera and Thal-Larsen (2008), Hashagen et al. (2009) and Strebel (2011). At the same time, the necessity to strengthen the confidence in the banking sector was supported by the lack of financial expertise of the members that were part of the administrative councils, which played a major role in generating this crisis Kirkpatrick (2009) and Walker (2009).

Bernadette Minton et al. (2011), is noticing that at the beginning of the financial crisis, for the financial institutions in the USA, the financial experience of the independent directors is low. Therefore, out of the 12 members, total of the board of directors of the financial company JP Morgan Chase, only two had financial expertise.

Macey and O'Hara (2003), Adams and Mehran (2003) have highlighted the health of the banking sector considering that this is more important than the health of other industries, its failure being able to determine the economic downfall of the countries that could have costly consequences.

This is the reason why the activity of the banking societies is very regulated comparing to other domains of activity. Nevertheless, the banking supervision and regulation authorities are encountering a series of difficulties to ameliorate the risk exposure, the final responsibility to manage these risks belonging to the board of directors, because there are deciding on the banks strategy, they decide on choosing the managers and set a range of operational politics for those (Van Greuning \& Brajovic Bratanovic, 2003). Thus, in order to avoid eventual failures (these being an important preoccupation of the decisional factors) and ensuring the fact that banks can identify, evaluate and manage efficiently the risks that they expose to, is necessary to set a rigorous discipline by establishing a set of regulations that are adequate and according to the banking governance. An adequate banking governance could contribute to losing the trust of the society towards the capacity to manage their own resources efficiently, therefore determining a liquidity crisis, consequently transposed in a systemic social and economic crisis (Cebenoyan \& Strahan, 2001; Alexander, 2006; Basel Committee on Banking Supervision, 2006; Garcia-Marco \& Robles-Fernandez, 2008).

A great range of academic studies have shown that during the financial crisis, a very important role in lowering the banking performance and the risk management respectively, was played by the deficiencies of the banking corporate governance (for example, Diamond \& Rajan, 2009). Considering this context, a recent analysis of OCDE has shown that the deficiencies of banking corporate governance had a great influence in generating the financial crisis (Kirkpatrick, 2009). Under this aspect, the topics on banking corporate governance needs to be given special attention in order to prevent and limit the opportunist behaviours, 
taking into account the effects on the banking performance, as well on the contributors, shareholders and creditors interests and needs (Srivastav \& Hagendorff, 2016).

Many recent studies on banking corporate governance are highlighting the risks governance, as well as the corporate governance mechanisms related to the efficient risk management (Miller, 1992; Miccolis \& Shaw, 2000; Cumming \& Mirtle, 2001; Nocco \& Stulz, 2006; Sabato, 2010). Acharya and Richardson (2009a) consider that it is necessary an efficient risk management that can prevent and limiting the excessive banks' exposure to risks.

Nițescu and Boitan (2017) reflect in one work about corporate governance in the banking domain, the fact that the approaches towards the risks, the categories of these risks, can be completed, can be regrouped, depending on the bank typology, on the way the activities happen, the operational complexity in which it is involved, the markets diversity on which it activates, the development of the products and services that are offered to the clients, the regulation environment, the interests and strategic vision of the bank, maturity and the risks culture, the previous experiences of risks management, the vulnerabilities and the identified opportunities of the banking institutions.

The study presented in this article contributes as well to developing the existing literature in what concerns the banking corporate governance, putting the emphasis on the banking system in Romania, aiming at finding the influences of the board of directors' structure that it has on the performance and banking management risks, in the context of the national and European regulations that are applicable for this domain. Moreover, if previous studies (ex: Aebi et al., 2012) were directed to emphasizing the influence of aspects concerning the corporate governance on the financial performance, by this present study we can analyse also the role played on the efficient risk management. An efficient risk management has become a generator of return, contributing to the increase of the portfolios (Negrei \& Istudor, 2018) of banking assets as well as decreasing the operational costs, giving credit this way to the previous researches regarding the corporate governance mechanisms on managing the risks.

Through this work, the authors are proposing to make an analysis of the impact of the structure of the boards of directors (by dimension, gender diversity, education, nationality and age of the members) on the performance and management of the risks on the Romanian banking system level. In what concerns the characteristics of the members of the board of directors, these were the subject of some previous researches such as: the gender diversity (Barber \& Odean, 2001; Carter et al., 2003; Erhardt et al., 2003; Dutta \& Bose, 2006; Bunea et al., 2018), the age (Hambrick \& Mason, 1984; Barker \& Mueller, 2002; Belenzon et al., 2019), education (Mintzberg, 2004; Gottesman \& Morey, 2010; Almășan et al., 2019), the origin country or nationality (Crossland \& Hambrick, 2011; Ioannou \& Serafeim, 2012; Boone et al., 2019). Avram et al. (2019) have noticed that one of the factors that affect the clarity when it comes to reporting the financial information, is the culture of the country in which the company is located.

The results of this research are indicating the fact that there is a positive and significant link between the members nationality and the boards of directors dimensions and the solvability of the analysed banks from the Romanian banking sector. In addition to that, there is a direct link of medium intensity between the level of the total own funds and the boards of directors characteristics, referring to the gender diversity, the members education and the 
dimension of the boards of director, as well as between the level of risk exposure of the banks and the gender diversity, as well as the boards of directors dimension where there is a direct and significant link, but not to that large extent.

Going further, the research is structures in this way: a section that is dedicated to the reviewing of the speciality literature in this domain, a section where it is presented the research methodology that is used, and another part in which the discussions, results of the research are debated and a last section including the conclusions of the authors.

\section{Review of the scientific literature}

Ever since 1977, Merton has claimed that the initiative to ensure the banking deposits has determined the shareholders to diversify the activities of acknowledging and preventing the risks that the banking societies are facing, in order to prevent possible failures. Moreover, considerations like "too big to fail" are offering default liabilities from the governments in order to mitigate the losses in the case in which the banking societies are facing problems (Acharya \& Richardson, 2009b).

In the context of corporate governance, the boards of directors being its key element, the componence and structure had to correspond to its basic functions, which is the supervision and monitoring of the company' activities, avoiding any inadequate and opportunist behaviour of the executive directors, as well as finding the best solutions and offering consultancy to the decisional factors that are determining the structe of the board of directors together with the impact on the company performance (Korent et al., 2014; Marinova et al., 2016, Terjesen et al., 2016; Borlea et al., 2017; Cavaco et al., 2016; Farag \& Mallin, 2017; Dinu \& Bunea, 2018). In addition to that, the international financial crisis has underlined a series of deficiencies in that concerns the corporate governance, such as the complexity and the soundness of the corporate governance of some companies, the lack of transparency and incapacity to face the crisis. Because of these deficiencies, it was generated the necessity to legislate and make a series of recommendations regarding the composition, the functions and the responsibilities of the board of directors, this being the most important corporate governance body (Korent et al., 2014; Murayev et al., 2016; Díaz et al., 2017; Bunea et al., 2015).

Therefore, considering that the main role played by the boards of directors is to advise and supervise the activities of the company, it is important to identify the characteristic of the members that can affect the capacity to successfully reach the main objective (Bunea, 2014; Bunea \& Dinu, 2019).

Regarding the risk management, the previous literature has emphasized the unique risk types without underlining the connection, interdependence between these risk categories (Miller, 1992). Thus, only in 1990, an integrated vision of the risk management concept has started to take shape (Cumming \& Mirtle, 2001; Miccolis \& Shaw, 2000; Miller, 1992; Nocco \& Stulz, 2006; Sabato, 2010). Also, on international level, the adequate character of the corporate governance of the financial institutions has started to be doubted by the public decisional factors. There have been examined the role and the profile of the risk management function in the banking and financial sector. At the same time, in a range of political documents, the aspects regarding the efficient risk management are presented in correlation to the corporate governance structures (Walker, 2009). A common recommendation was the "putting the high 
risk on the agenda" of the administrative councils and creating structures that can ensure the efficient management of the risks that the banks are facing. As it has been claimed ever since 2002 by Sarbanes-Oxley Act (SOX), the financial expertise is evaluated to be having a very important role in managing the risks and performance of the companies. A series of other specific measures are referring to a risk management committee (of a CRO-Chief Risk Officer) supposed to have the supervision role of all the relevant risks that the organization is exposing to (for instance, Brancato et al., 2009; Sabato, 2010).

Mongiardino and Plath (2010) are believing that the amelioration of the risks exposure can be limited only to a certain extent in what concerns the big banks, despite the excessive pressure of a regulations induced by the financial crisis. These regulations are shaping the best practices for the banking risks management, emphasizing also the necessity of risk management committee in the ferule of the boards of directors.

Even if the importance and roles of the boards of directors' structure when it comes to risks governance in the banking sector were highlighted in a series of studies (Banham, 2000; Brancato et al., 2009; Dinu \& Bunea, 2018), there were not many significant works in the in the academic literature up until now. Among these, a study conducted by Ellul and Yerramilli (2013) is pointing out the strong and significant connection between the banking management structure and the risk management instruments as well as the banks performance in the time of credits risk, the study being conducted on a sample of 74 big banking companies of holding type in the USA.

In addition to that, in the speciality literature there are a few academic studies that have analysed a series of other aspects of corporate governance for the banking societies, such as the characteristics and the boards of directors composition, the wage structure and the way the remuneration of the CEO or executive president is being set (for instance, Beltratti \& Stulz, 2010; Erkens et al., 2012; Fahlenbrach \& Stulz, 2011; Minton et al., 2011).

The analysis of the influence of the corporate governance on the banking performance indicators have been subject of the researches conducted by Beltratti and Stulz (2011) and Fahlenbrach and Stulz (2011) respectively. Beltratti and Stulz (2011) have studied the relationship between the banking performance and corporate governance during the financial crisis over an international sampling of 98 banks. In their research, Beltratti and Stulz are underlining that the banks that were sustained by the boards of directors in order to maximize the wealth of the stockholders have been exposed to a range of risks in the favour of the stockholders' fortune, these risks generating a series of costs that have not been foreseen prior to exposing to risk of the banking societies.

Also, Erkens et al. (2012) are studying the relationship between the corporate governance structure and the financial performance indicators of the financial companies during the credits' crisis of 2007-2008, the performance being conducted on a sample of 296 financial companies out of 30 countries. These are claiming in their work the fact that companies of big dimension have taken a series a excessive risks between entering the crisis, this determining the register of significant losses on the side of stakeholders in the context of financial crisis (Savoiu et al., 2012).

Boitan and Nițescu (2019) have made an integrated research, which examine the quality of corporate governance, for a panel of 29 most representative banks in Europe (banks of sys- 
temic importance - GSIFIs), investigating to which extent the managerial efficiency is being determined by characteristics of the boards of directors (the board's dimension, the gender diversity, the number of the independent members). The study is examining if the managerial efficiency of the boards and the its characteristics have impact on the relevant indicators, not only on banking organizations level but also on the overall banking system level.

Minton et al. (2011) are researching the way in which the excessive risks exposure and the indicators regarding the performances of the American banking sector are dependent on the structure, characteristics and financial experience of the members belonging to the banking board of directors. The increase of the banking assets and decrease of the operational costs (Vuță et al., 2019) are considered by the majority of the banks to be the main profitability factors. The efficient risk management has in most of the time the role of supporting function and control of the banking activity (Aebi et al., 2012).

In 2008, in his letter to the stakeholders Berkshire Hathaway Inc., Warren Buffet has claimed that "the general manager of any financial organization of big dimensions has to be also the main responsible when it comes to the risks that the organization is facing".

In their work, Aebi et al. (2012) are stating that the banks need to significantly improve the risks management function and have a direct reporting relationship with the boards, in order to face a possible financial crisis.

Taking into consideration that the boards of directors is the key element of the corporate governance, it is absolutely necessary that its structure and characteristics are according to the basic functions: monitoring and supervision, avoiding and preventing the opportunist behaviour of the executive managers and offering recommendations and consultancy for decision making, aiming at improving the financial performances and managing efficiently the risks that the organization is exposing to.

Also, in the speciality literature, there is a particular focus on promoting the knowledge diversity, on the abilities and experience (Mateos de Cabo et al., 2010). Moreover, on European level, the gender diversity is being supported with the recommendation of the European Commission that women - members of the administrative councils to hold a percentage of $30 \%$ of the total of the members. It has to be analysed the extent to which these recommendations become applicable equally to all the companies. Studies of some authors like Raheja (2005), Boone et al. (2007), Guest (2009), Lehn et al. (2009), Acero and Alcade (2012) and Farag and Mallin (2017), are claiming that the composition and the structure of the boards of directors are influenced by the business environment of the company, its characteristics and information needs in the relationship with the business partners.

Regarding the age of the boards members, Hambrick and Mason (1984), have showed in their studies a positive relationship between the young managers and the increase of the performances of the company. At the same time, the elder managers have the tendency to be more conservatories, being more reticent when it comes to taking risks. The same results can be found in the studies conducted by Barker and Mueller (2002).

The nationality, as a characteristic of the boards members, is part of the studies conducted by Crossland and Hambrick (2011). These two have highlighted the fact that a series of characteristics of the origin country, such as the individualism, focusing on property and the tolerance to uncertainty, can be linked to the managerial attitude of the members of 
the administrative council, who can also have an impact on the financial performance of the company. The same conclusion can be found in the studies of the authors Ioannou and Serafeim (2012) who say that forming and education in a national level in domains such as politics, social, education, cultural or even regarding the work relationships that inevitably have an impact on the social performances of the companies. Therefore, as per the evidence of the speciality literature, the nationality (Vătămănescu et al., 2018) can influence the performance of a company by using the expertise received in the origin country (political influence, education, culture and work relationships) (Ioannou \& Serafeim, 2012), as well as the manager's principles and values.

\section{The relationship between the characteristics of the boards of directors and the risk management exposure together with the capital demands of the banks in the Romanian banking system}

The main objective of this study is to identify the potential interdependence between the characteristics of the boards of directors from the Romanian banking system and the risk exposure together with the capital demands.

Therefore, this work aims at offering an exhaustive analysis of the potential relationship between the boards of directors, on one hand, and the risk management and the capital demands of the banks from the Romanian banking system, on the other hand, trying at the same time to find the argumentative answer through the results of this empirical research to the question: does it influence or not and if the answer is yes, to what extent, what is the intensity level that the influence of the characteristics of the administrative council affects the level of the risks exposure and the capital demands of the banks?

Taking into consideration the results of some studies from the speciality literature, the authors have formulated four hypotheses:

H1: There is significant positive relationship between the boards of directors' characteristics and the banks solvability.

$\mathrm{H} 2$ : There is significant positive relationship between the boards of directors' characteristics and the banks' total funds.

H3: There is significant positive relationship between the boards of directors' characteristics and level or risk exposure (RWA).

H4: There is significant positive relationship between the boards of directors' characteristics and RWA - credit risk, RWA - market risk and respectively RWA - operational risk.

\section{The research methodology}

The research methodology used for the testing of the formulated hypotheses, is mostly quantitative, based on the deductive statistical analysis, in which the starting point is the agency theory with a series of testing objectives and potential cause and effect links, as well as the analysis of its significance level.

The characteristics of the boards of directors from the Romanian banking system, are analysed depending on the size, gender diversity, the presence of the women in the total boards composition, the members age, the financial education and the origin country. 
In this study, the specific instruments to process the necessary data were obtained by using the SPSS for Windows software (the regression analysis and the correlation tests).

At the end of 2018, in the Romanian banking system, there were 33 credit institutions out of which 26 are banks, Romanian legal entities and 5 are headquarters of some foreign banks.

Out of the 33 credit institutions, the studied sample consists of 25 banks, Romanian legal entities where the information was extracted from official websites and the information was published at the end of the financial year of 2018, being eliminated from the analysis the seven headquarters of the foreign banks, for which, the National Bank of Romania regulation system no 25/30/2006 regarding the way the information should be presented for the credit institutions and investments institutions, there is no obligation to publish the information on Romanian territory (these are becoming public in the origin country of the group of the respective headquarter) as well as a bank, a Romanian legal person that did not have the information published on the official website.

This research was based exclusively on the information posted on the official websites of the banks, of the Romanian Bank of Romania or the reports regarding the financial year of 2018 regarding the transparency and confidence requirements in accordance to the regulations of NBR.

To accomplish the objectives of this study, it was needed to define two categories of distinctive variables, meaning: the independent variables and the dependent variables, trying to analyse the correlation between these two. In Table 1, it is presented in detail the situation of the independent variables, the way in which they were defined and also the way in which they were determined.

Table 1. The situation of the independent variables (source: the authors' own work)

\begin{tabular}{|l|l|l|l|}
\hline \multicolumn{1}{|c|}{ Independent variable } & Used Symbol & \multicolumn{1}{|c|}{ The variable definition } & \multicolumn{1}{|c|}{ Determination means } \\
\hline Size & CA_Size & $\begin{array}{l}\text { The number of the boards' } \\
\text { members }\end{array}$ & Number of the members \\
\hline Gender diversity & CA_Divg & $\begin{array}{l}\text { The percentage of the } \\
\text { women in the total number } \\
\text { of the boards' members }\end{array}$ & $\begin{array}{l}\text { The number of women/total } \\
\text { number of members }\end{array}$ \\
\hline Education & CA_Educ & $\begin{array}{l}\text { The percentage of the } \\
\text { members with financial } \\
\text { expertise out of the boards' } \\
\text { members }\end{array}$ & $\begin{array}{l}\text { The number of the members } \\
\text { with financial education/ } \\
\text { total number of members }\end{array}$ \\
\hline Nationality & CA_Nat & $\begin{array}{l}\text { The percentage of the } \\
\text { members of Romanian } \\
\text { nationality }\end{array}$ & $\begin{array}{l}\text { The number of members } \\
\text { who have Romania as origin } \\
\text { country/total number of } \\
\text { members }\end{array}$ \\
\hline Age & CA_Age & $\begin{array}{l}\text { The average age of the } \\
\text { members that are part of the } \\
\text { boards' members }\end{array}$ & $\begin{array}{l}\text { The sum of the members' } \\
\text { age that are part of the } \\
\text { board divided by their } \\
\text { number }\end{array}$ \\
\hline
\end{tabular}

Concerning the capital requirements and risk management, the analysed dependent variables are the following: the solvency indicator, the level of the own total funds, the weighted 
assets to risk (RWA) and the level of exposure for each risk category - de creditrisk, market risk and operational risk.

The own funds, as per the Basel 3 Agreement requirements are made of the following components: CET1 - The basic I rang Capital, AT1 - The additional level I and T2 - The own funds of level 2. In order to determine the capital indicators, every capital component, after considering all the filters and deductions, is compared to the total risk. In accordance to the Regulation regarding the Capital requirements, the minimum level for CET1 is of 4.5\%, which can be majored in accordance to the system of the capital absorber of CRD IV. The minimum requirement for the type I Capital (CET 1 plus AT1) and for the total own funds is of $6 \%$ and $8 \%$ respectively.

The banks are in charge with the monitoring of the capital indicators, as per the financial situations that are in accordance to the Financial Reporting of International Standards (IFSR). The total capital requirement for the credit risk is calculated as being $8 \%$ of the weighted assets to risk. Also, in order to calculate the adequacy rate of the capital, the banks are considering the capital requirement for the market and operations risks.

According to the Basel Agreement, the ICAAP framework (The Internal Process of Evaluation of the Risk Capital Adequacy) and the Calculation of the cover capacity of the risks (RCC) represent the components of the Pile II requirements. The calculation of the cover capacity of the risks is a model that determines the relevant exposures from the risk point of view for all types of banks and compare them to the capital and cover potential of the capital on a bank level, which is necessary to cover when it comes to those risks. The calculation of the risks volume is a bedrock of determining the capital requirement for covering the unexpected losses when it comes to the credit risk, market risk and operational risk.

As the weighted assets to risk (RWA) determine the regulated capital requirement of the bank and influence the capital indicator as a key performance indicator, special attention was given to accomplishing the objectives and the capacity to plan and foresee for this parameter. The information from the monthly analysis related to the weighted assets to risks are used to improve the infrastructure of the calculation, the quality of the in parameters and the data, as well as applying more efficiently the Basel framework overall.

Therefore, the banks are calculating the rate of capital adequacy regulated as per No 575/2013 Governing Rules of the European Parliament and Council of $26^{\text {th }}$ of June 2013 regarding the prudential requirements for the credit institutions and investments societies.

In Table 2, the situation of the dependent variables is presented together with the denomination, the used symbol, the definition and way of determination.

In order to test the potential correlations between the independent variables and the dependent ones, the authors of this study have used as an instrument the Pearson quotient, a quotient that is most frequently used to evaluate the intensity of a linear dependency between two variables. This can take values between "1" (value that emphasizes a direct and perfect relationship) and " -1 " respectively (which indicates the inexistency of a linear relationship between the two variables). This research of the possible relationship between the two types of analysed variables offer clues on the sense and significance of eventual connections, therefore permitting the rejection or acceptance of the formulated study hypotheses. 
Table 2. The situation of the dependent variables (source: own work of the authors)

\begin{tabular}{|l|l|l|l|}
\hline \multicolumn{1}{|c|}{$\begin{array}{c}\text { Dependent } \\
\text { variable }\end{array}$} & \multicolumn{1}{|c|}{$\begin{array}{c}\text { Used } \\
\text { Symbol }\end{array}$} & The variable definition & \multicolumn{1}{|c|}{ The way of determination } \\
\hline $\begin{array}{l}\text { The solvency } \\
\text { indicator }\end{array}$ & Solv & $\begin{array}{l}\text { The rate of the capital } \\
\text { adequacy }\end{array}$ & $\begin{array}{l}\text { The percentage of the own funds in the } \\
\text { total of the weighted assets to risks }\end{array}$ \\
\hline The own funds & Fd_pr & $\begin{array}{l}\text { The total value of own } \\
\text { funds }\end{array}$ & $\begin{array}{l}\text { The sum between the type I basic capitals, } \\
\text { AT1, additional level I and T2 capitals - } \\
\text { Own funds of Level 2 }\end{array}$ \\
\hline $\begin{array}{l}\text { The assets } \\
\text { weighted to risk }\end{array}$ & RWA & The risk exposure value & $\begin{array}{l}\text { The total of the assets of the banking } \\
\text { society multiplied by a risk percentage } \\
\text { that is specific to every category of assets }\end{array}$ \\
\hline $\begin{array}{l}\text { RWA for credit } \\
\text { risk }\end{array}$ & RWA_RC & $\begin{array}{l}\text { The value of exposure to } \\
\text { the credit risk }\end{array}$ & The total exposure to the credit risk \\
\hline $\begin{array}{l}\text { RWA for the } \\
\text { operational risk }\end{array}$ & RWA_RO & $\begin{array}{l}\text { The value of exposure to } \\
\text { the operational risk }\end{array}$ & The total exposure to the operational risk \\
\hline $\begin{array}{l}\text { RWA for the } \\
\text { market risk }\end{array}$ & RWA_RP & $\begin{array}{l}\text { The value of exposure to } \\
\text { the market risk }\end{array}$ & The total exposure to the market risk \\
\hline
\end{tabular}

\section{Results and discussion}

In this research, for each independently analyzed variable, the study of each identified influence, which offers an argument for rejecting or accepting the formulated hypotheses, is based on a series of results of a linear regression analysis (the multiple regression model under SPSS or the Backward method), being described below in detail (the results of this analysis are found in the Tables 3, 6, 9 "Model summary", Tables 4, 7, 10 "Partial correlation matrix" and Tables 5, 8, 11 "ANOVA results" using SPSS software).

Table 3. Model summary ${ }^{\mathrm{e}}$ (source: the authors' own work using SPSS soft)

\begin{tabular}{|c|c|c|c|c|}
\hline Model & R & R Square & Adjusted R Square & Std. Error of the Estimate \\
\hline 1 & $.623^{\mathrm{a}}$ & .388 & .227 & 1.91346 \\
\hline 2 & $.618^{\mathrm{b}}$ & .382 & .258 & 1.87476 \\
\hline 3 & $.603^{\mathrm{c}}$ & .364 & .273 & 1.85632 \\
\hline 4 & $.531^{\mathrm{d}}$ & .282 & .217 & 1.92572 \\
\hline
\end{tabular}

Notes: a. Predictors: (Constant), gender diversity, members nationality, board size, members education, members age; b. Predictors: (Constant), members nationality, board size, members education, members age; c. Predictors: (Constant), members nationality, board size, members age; d. Predictors: (Constant), members nationality, board size; e. Dependent Variable: solvency.

Regarding the testing of Hypothesis $\mathrm{H} 1$ : Whether there is a positive significant association between the characteristics of the boards of directors and the banks solvency, the research was focused on their impact (as independent variables) on the weight of the total own funds in the total risk exposure value at the level of each analyzed bank.

Thus, the results of the research regarding the independent variables influence on the bank's solvency are detailed in the Table 3 (Model summary), the Table 4 (Corellations) and the Table 5 (ANOVA). In this analysis, the $\mathrm{R}$ value, the adjusted $\mathrm{R}^{2}$ value and the standard er- 
ror indicate that a possible influence (the independent variables that can provide an estimate of the dependent variable) on the banks solvency has the members nationality (the country of the members origin) and the size of the Board of Directors.

Table 4. Correlations (source: the authors' own work using SPSS soft)

\begin{tabular}{|l|l|c|c|c|c|c|c|}
\hline \multicolumn{2}{|c|}{} & solvab & size & age & nation & educ & Gender div \\
\hline \multirow{4}{*}{$\begin{array}{l}\text { Pearson } \\
\text { Corre- } \\
\text { lation }\end{array}$} & Solvency & 1.000 & -.427 & .022 & .363 & .101 & -.229 \\
\cline { 2 - 8 } & Board size & .627 & 1.000 & .315 & -.115 & -.101 & .137 \\
\cline { 2 - 8 } & Members age & .022 & .315 & 1.000 & -.346 & -.144 & -.228 \\
\cline { 2 - 8 } & Members nationality & .663 & -.115 & -.346 & 1.000 & -.080 & .028 \\
\cline { 2 - 8 } & Members education & .101 & -.101 & -.144 & -.080 & 1.000 & -.182 \\
\cline { 2 - 8 } & Gender diversity & -.229 & .137 & -.228 & .028 & -.182 & 1.000 \\
\hline \multirow{4}{*}{$\begin{array}{l}\text { Sig. } \\
(1-\text { tailed }\end{array}$} & Solvency &. & .017 & .459 & .037 & .315 & .136 \\
\cline { 2 - 8 } & Board size & .004 &. & .062 & .293 & .315 & .257 \\
\cline { 2 - 8 } & Members age & .459 & .062 &. & .045 & .246 & .137 \\
\cline { 2 - 8 } & Members nationality & .003 & .293 & .045 &. & .351 & .447 \\
\cline { 2 - 8 } & Members education & .315 & .315 & .246 & .351 &. & .192 \\
\cline { 2 - 8 } & Gender diversity & .136 & .257 & .137 & .447 & .192 &. \\
\hline \multirow{5}{*}{ N } & Solvency & 25 & 25 & 25 & 25 & 25 & 25 \\
\cline { 2 - 8 } & Board size & 25 & 25 & 25 & 25 & 25 & 25 \\
\cline { 2 - 8 } & Members age & 25 & 25 & 25 & 25 & 25 & 25 \\
\cline { 2 - 8 } & Members nationality & 25 & 25 & 25 & 25 & 25 & 25 \\
\cline { 2 - 8 } & Members education & 25 & 25 & 25 & 25 & 25 & 25 \\
\cline { 2 - 8 } & Gender diversity & 25 & 25 & 25 & 25 & 25 & 25 \\
\hline
\end{tabular}

Table 5. ANOVA ${ }^{\text {a }}$ (source: the authors' own work using SPSS soft)

\begin{tabular}{|c|l|c|c|c|c|c|}
\hline \multicolumn{2}{|c|}{ Model } & Sum of Squares & df & Mean Square & F & Sig. \\
\hline \multirow{3}{*}{1} & Regression & 44.135 & 5 & 8.827 & 2.411 & $.075^{\mathrm{b}}$ \\
\cline { 2 - 8 } & Residual & 69.565 & 19 & 3.661 & & \\
\cline { 2 - 8 } & Total & 113.700 & 24 & & & \\
\hline \multirow{3}{*}{2} & Regression & 43.406 & 4 & 10.852 & 3.087 & $.039^{\mathrm{c}}$ \\
\cline { 2 - 8 } & Residual & 70.294 & 20 & 3.515 & & \\
\cline { 2 - 8 } & Total & 113.700 & 24 & & & \\
\hline \multirow{3}{*}{3} & Regression & 41.336 & 3 & 13.779 & 3.999 & $.021^{\mathrm{d}}$ \\
\cline { 2 - 8 } & Residual & 72.365 & 21 & 3.446 & & \\
\cline { 2 - 8 } & Total & 113.700 & 24 & & & $.004^{\mathrm{e}}$ \\
\hline \multirow{3}{*}{4} & Regression & 32.116 & 2 & 16.058 & 4.330 & \\
\cline { 2 - 8 } & Residual & 81.585 & 22 & 3.708 & & \\
\cline { 2 - 8 } & Total & 113.700 & 24 & & & \\
\hline
\end{tabular}

Notes: a. Dependent Variable: solvency; b. Predictors: (Constant), gender diversity, members nationality, board size, members education, members age; c. Predictors: (Constant), members nationality, board size, members education, members age; d. Predictors: (Constant), members nationality, board size, members age; e. Predictors: (Constant), members nationality, board size. 
The same conclusion results from the Matrix of possible correlations, where it is observed that the most significant relationship is between the members nationality and respectively the Board of Directors size and the bank solvency indicator. Thus, between the dependent variable "Solvency" and the independent variables there is a direct link. The value of the correlation coefficient is equal to 0.627 and 0.663 respectively, with a value Sig. (significance threshold) less than 0.05 .

Thus, the result of the research indicates that there is a significant positive association between the members' nationality and the Board of Directors size and the analyzed banks solvency in the Romanian banking sector.

Regarding the second hypothesis, respectively $\mathrm{H} 2$ : Whether there is a positive significant relationship between the boards of directors characteristics and the banks total own funds, the research results indicate a directly significant relationship between the independent variables: gender diversity, financial education of the members and the Board of Directors size and the dependent variable -the total level of own funds of the analyzed banks. The results of the research of the relationship between these two types of variables are found in Tables 6 , 7 and 8.

Table 6. Model summary ${ }^{\mathrm{d}}$ (source: the authors' own work using SPSS soft)

\begin{tabular}{|c|c|c|c|c|}
\hline Model & $\mathrm{R}$ & R Square & Adjusted R Square & Std. Error of the Estimate \\
\hline 1 & $.807^{\mathrm{a}}$ & .652 & .560 & 1.02085 \\
\hline 2 & $.806^{\mathrm{b}}$ & .650 & .581 & .99703 \\
\hline 3 & $.804^{\mathrm{c}}$ & .646 & .595 & .97926 \\
\hline
\end{tabular}

Notes: a. Predictors: (Constant), gender diversity, members nationality, board size, members education, members age; b. Predictors: (Constant), gender diversity, board size, members education, members age; c. Predictors: (Constant), gender diversity, board size, members education; d. Dependent Variable: the total level of own funds.

Table 7. Correlations (source: the authors' own work using SPSS soft)

\begin{tabular}{|l|l|c|c|c|c|c|c|}
\hline \multicolumn{2}{|c|}{} & Own funds & size & age & nation & educ & Gender div \\
\hline $\begin{array}{l}\text { Pearson } \\
\text { Corre- } \\
\text { lation }\end{array}$ & Own funds & 1.000 & .663 & .095 & -.048 & -.399 & .449 \\
\cline { 2 - 8 } & Board size & .663 & 1.000 & .315 & -.115 & -.101 & .137 \\
\cline { 2 - 8 } & Members age & .095 & .315 & 1.000 & -.346 & -.144 & -.228 \\
\cline { 2 - 8 } & Members nationality & -.048 & -.115 & -.346 & 1.000 & -.080 & .028 \\
\cline { 2 - 8 } & Members education & .599 & -.101 & -.144 & -.080 & 1.000 & -.182 \\
\cline { 2 - 8 } & Gender diversity & .649 & .137 & -.228 & .028 & -.182 & 1.000 \\
\hline \multirow{4}{*}{$\begin{array}{l}\text { Sig. } \\
(1-\text { tailed) }\end{array}$} & Own funds & .000 & .326 & .410 & .024 & .012 & \\
\cline { 2 - 8 } & Board size & .000 &. & .062 & .293 & .315 & .257 \\
\cline { 2 - 8 } & Members age & .326 & .062 &. & .045 & .246 & .137 \\
\cline { 2 - 8 } & Members nationality & .410 & .293 & .045 &. & .351 & .447 \\
\cline { 2 - 8 } & Members education & .004 & .315 & .246 & .351 &. & .192 \\
\cline { 2 - 8 } & Gender diversity & .002 & .257 & .137 & .447 & .192 &. \\
\hline
\end{tabular}


End of Table 7

\begin{tabular}{|l|l|c|c|c|c|c|c|}
\hline \multicolumn{2}{|c|}{} & Own funds & size & age & nation & educ & Gender div \\
\hline \multirow{3}{*}{$\mathrm{N}$} & Own funds & 25 & 25 & 25 & 25 & 25 & 25 \\
\cline { 2 - 8 } & Board size & 25 & 25 & 25 & 25 & 25 & 25 \\
\cline { 2 - 8 } & Members age & 25 & 25 & 25 & 25 & 25 & 25 \\
\cline { 2 - 8 } & Members nationality & 25 & 25 & 25 & 25 & 25 & 25 \\
\cline { 2 - 8 } & Members education & 25 & 25 & 25 & 25 & 25 & 25 \\
\cline { 2 - 8 } & Gender diversity & 25 & 25 & 25 & 25 & 25 & 25 \\
\hline
\end{tabular}

Table 8. ANOVA ${ }^{\text {a }}$ (source: the authors' own work using SPSS soft)

\begin{tabular}{|c|l|c|c|c|c|c|}
\hline \multicolumn{2}{|c|}{ Model } & Sum of Squares & df & Mean Square & F & Sig. \\
\hline \multirow{3}{*}{1} & Regression & 37.075 & 5 & 7.415 & 7.115 & $.001^{\text {b }}$ \\
\cline { 2 - 7 } & Residual & 19.801 & 19 & 1.042 & & \\
\cline { 2 - 7 } & Total & 56.875 & 24 & & & \\
\hline \multirow{3}{*}{2} & Regression & 36.994 & 4 & 9.248 & 9.304 & $.000^{\text {c }}$ \\
\cline { 2 - 7 } & Residual & 19.881 & 20 & .994 & & \\
\cline { 2 - 7 } & Total & 56.875 & 24 & & & $.000^{\text {d }}$ \\
\hline \multirow{3}{*}{3} & Regression & 36.737 & 3 & 12.246 & 12.770 & \\
\cline { 2 - 7 } & Residual & 20.138 & 21 & .959 & & \\
\cline { 2 - 7 } & Total & 56.875 & 24 & & & \\
\hline
\end{tabular}

Notes: a. Dependent Variable: own funds; b. Predictors: (Constant), gender diversity, members nationality, board size, members education, members age; c. Predictors: (Constant), gender diversity, board size, members education, members age; $d$. Predictors: (Constant), gender diversity, board size, members education.

The same conclusion can be drawn if we consider the results from the Table 8 ANOVA. When the Sig. value is less than 0.05 , the independent variables explain in a very large proportion the variation of the dependent variables. In our analysis, the variation of the total own funds depends to a large extent on the three indicators, respectively the gender diversity, the members education and the Board of Directors size.

Regarding the total own funds level, because the Pearson coefficient value is $0.663,0.599$ and respectively 0.649 with the Sig. value below 0.05 , it suggests that there is a direct link between the analyzed dependent variable and the independent variables. Thus, the second research formulated hypothesis (H2) can be accepted; we can say that there is a direct association of average intensity between the own funds level and the board of directors characteristics, respectively the gender diversity, the members education and the Board of Directors size.

Regarding the hypothesis $\mathrm{H} 3$ testing: There is a significant positive association between the board of directors characteristics and the value of the risk-weighted assets of the analyzed banks, the research results indicate a direct relation between the banks risk exposure and the gender diversity and the Board of Directorssize. The results of the research regarding the relationship between the risk exposures and the independent variables are found in the Tables 9 , 10 and 11 . Thus, the $\mathrm{R}$ value, the adjusted $\mathrm{R}^{2}$ value and the standard error demonstrate that 
the best predictors (those independent values that best estimate the dependent variable) are the gender diversity and the Board of Directors size.

Table 9. Model summary (source: the authors' own work using SPSS soft)

\begin{tabular}{|c|c|c|c|c|}
\hline Model & R & R Square & Adjusted R Square & Std. Error of the Estimate \\
\hline 1 & $.795^{\mathrm{a}}$ & .632 & .535 & 1.24119 \\
\hline 2 & $.795^{\mathrm{b}}$ & .632 & .558 & 1.21021 \\
\hline 3 & $.785^{\mathrm{c}}$ & .617 & .562 & 1.20474 \\
\hline 4 & $.753^{\mathrm{d}}$ & .567 & .528 & 1.25108 \\
\hline
\end{tabular}

Notes: a. Predictors: (Constant), gender diversity, members nationality, board size, members education, members age; b. Predictors: (Constant), gender diversity, board size, members education, members age; c. Predictors: (Constant), gender diversity, board size, members education; d. Predictors: (Constant), gender diversity, board size; e. Dependent Variable: the banks risk exposure (RWA).

Table 10. Correlations (source: the authors' own work using SPSS soft)

\begin{tabular}{|l|l|c|c|c|c|c|c|}
\hline \multicolumn{2}{|c|}{} & RWA & size & age & Nation & Educ & Gender div \\
\hline \multirow{4}{*}{$\begin{array}{l}\text { Pearson } \\
\text { Corre- } \\
\text { lation }\end{array}$} & RWA & 1.000 & .692 & .283 & -.105 & -.339 & .388 \\
\cline { 2 - 8 } & Board size & .592 & 1.000 & .315 & -.115 & -.101 & .137 \\
\cline { 2 - 8 } & Members age & .283 & .315 & 1.000 & -.346 & -.144 & -.228 \\
\cline { 2 - 8 } & Members nationality & -.105 & -.115 & -.346 & 1.000 & -.080 & .028 \\
\cline { 2 - 8 } & Members education & -.339 & -.101 & -.144 & -.080 & 1.000 & -.182 \\
\cline { 2 - 8 } & Gender diversity & .588 & .137 & -.228 & .028 & -.182 & 1.000 \\
\hline \multirow{4}{*}{$\begin{array}{l}\text { Sig. } \\
(1-\text { tailed }\end{array}$} & RWA &. & .000 & .085 & .309 & .049 & .028 \\
\cline { 2 - 8 } & Board size & .000 &. & .062 & .293 & .315 & .257 \\
\cline { 2 - 8 } & Members age & .085 & .062 &. & .045 & .246 & .137 \\
\cline { 2 - 8 } & Members nationality & .309 & .293 & .045 &. & .351 & .447 \\
\cline { 2 - 8 } & Members education & .049 & .315 & .246 & .351 &. & .192 \\
\hline \multirow{5}{*}{ N } & Gender diversity & .002 & .257 & .137 & .447 & .192 &. \\
\cline { 2 - 8 } & RWA & 25 & 25 & 25 & 25 & 25 & 25 \\
\cline { 2 - 8 } & Board size & 25 & 25 & 25 & 25 & 25 & 25 \\
\cline { 2 - 8 } & Members age & 25 & 25 & 25 & 25 & 25 & 25 \\
\cline { 2 - 8 } & Members nationality & 25 & 25 & 25 & 25 & 25 & 25 \\
\cline { 2 - 8 } & Members education & 25 & 25 & 25 & 25 & 25 & 25 \\
\cline { 2 - 8 } & Gender diversity & 25 & 25 & 25 & 25 & 25 & 25 \\
\hline
\end{tabular}

Table 11. ANOVA ${ }^{\text {a }}$ (source: the authors' own work using SPSS soft)

\begin{tabular}{|c|l|c|c|c|c|c|}
\hline \multicolumn{2}{|c|}{ Model } & Sum of Squares & df & Mean Square & F & Sig. \\
\hline \multirow{3}{*}{1} & Regression & 50.253 & 5 & 10.051 & 6.524 & $.001^{\text {b }}$ \\
\cline { 2 - 7 } & Residual & 29.270 & 19 & 1.541 & & \\
\cline { 2 - 7 } & Total & 79.523 & 24 & & & \\
\hline
\end{tabular}


End of Table 11

\begin{tabular}{|c|l|c|c|c|c|c|}
\hline \multicolumn{2}{|c|}{ Model } & Sum of Squares & df & Mean Square & F & Sig. \\
\hline \multirow{3}{*}{2} & Regression & 50.231 & 4 & 12.558 & 8.574 & $.000^{\mathrm{c}}$ \\
\cline { 2 - 7 } & Residual & 29.292 & 20 & 1.465 & & \\
\cline { 2 - 7 } & Total & 79.523 & 24 & & & \\
\hline \multirow{3}{*}{3} & Regression & 49.044 & 3 & 16.348 & 11.264 & $.000^{\mathrm{d}}$ \\
\cline { 2 - 7 } & Residual & 30.479 & 21 & 1.451 & & \\
\cline { 2 - 7 } & Total & 79.523 & 24 & & & $.000^{\mathrm{e}}$ \\
\hline \multirow{3}{*}{4} & Regression & 45.089 & 2 & 22.545 & 14.404 & \\
\cline { 2 - 8 } & Residual & 34.434 & 22 & 1.565 & & \\
\cline { 2 - 8 } & Total & 79.523 & 24 & & & \\
\hline
\end{tabular}

Notes: a. Dependent Variable: RWA; b. Predictors: (Constant), gender diversity, members nationality, board size, members education, members age; c. Predictors: (Constant), gender diversity, board size, members education, members age; d. Predictors: (Constant), gender diversity, board size, members education; e. Predictors: (Constant), gender diversity, board size.

The same conclusions can be drawn from the Table 11- ANOVA, (if the value Sig. is less than 0.05 ), the independent variables explain in a significant way the dependent variable variation, in correlation of course with the Pearson coefficient value. Thus the smallest values (below 0.05) of Sig. are those related to the independent variables: gender diversity and the Board of Directors size, showing a significant association between the risk exposure level of the analyzed banks and these independent variables, taken in our study as the Board of Directors characteristics.

Because the Person coefficient values are slightly above the 0.500 value, we consider that the relation between the dependent variable and the independent variables is a direct significant one. Thus, the third hypothesis formulated can be accepted, respectively, that between the banks risk exposures level and the gender diversity and the Board of Directors size, there is a direct slightly significant connection.

Regarding the testing of the fourth formulated hypotheses, respectively (H4) There is or not a significant positive association between the characteristics of the boards and the risk weighted exposures, the risk weighted assets (RWA) related to the credit risk, the weighted assets at risk (RWA) related to market risk and respectively risk weighted assets (RWA) related to operational risk, the research results are as follows:

- regarding the level of exposure to RWA weighted risks - credit risk, we find a Person Coefficient value greater than 0.500 with Sig. below the 0.05 level, which indicates a direct positive association, like the testing of hypothesis $\mathrm{H} 3$, between the credit risk exposure as the dependent variable and the independent variables: the gender diversity and the board of directors size;

- for testing the relationship between the market risk exposure and the independent variables, we find a directly negative and significant association between it and the financial members education of the Board of Directors. The resulting Pearson coefficient has a value of -0.574 and the Sig. level. is 0.001 , which shows a directly signif- 
icant reverse link, respectively, the higher the exposure to market risk, the lower the share of members with financial education in the Board of Directors composition.

- regarding a potential relationship between the exposure to the operational risks of the banks and the independent variables, the research results do not indicate the existence of a possible association between the two categories of variables.

\section{Conclusions}

The study was designed to provide an analysis of the possible relationships between the characteristics of the banks boards from the Romanian banking system and the management of risks exposures, the capital requirements of the banks, as a priority component of the Basel Agreement.

The analysis of the potential links between the boards of directors characteristics and the banking financial performances has been the subject of previous research, but, the novelty element that this paper presents is that it extends the analysis on the level of risk exposures of banks going to test the possible associations with exposure on the respective types of risks: credit risk, risk and operational risk. The calculation of the risks volume is based on the capital requirement determination to cover unexpected losses in terms of credit risk, market risk and operational risk, this calculation of risk coverage capacity (RCC) representing components of the II Basel Pillar requirements.

At the Romanian banking system level is the first research that tries to capture the relation between the board of directors characteristics such as nationality, age, financial education and the level of exposures to credit, market and operational risks, as major requirements of the Basel Agreement.

However, the paper presents a series of limits generated in the first by the small number of banks included in the researched sample, the situation of the banks operating in the Romanian banking system knowing a downward evolution in recent years. We appreciate that, with all these limitations, the present paper is a challenge for the future research in this field, by extending the analysis over a larger period of time (including in the evolution of the indicators analyzed over several years in the study), which may be important source of information and reflection for practitioners and not only for them.

\section{Acknowledgements}

The authors thank the editor and reviewers for their comments and suggestions.

\section{Funding}

This work has received no funding.

\section{Author contributions}

The authors conceived the study and were responsible for the design of the methodology, for data collection and interpretation. 


\section{Disclosure statement}

The authors declare no conflict of interest.

\section{References}

Abou-El-Sood, H. (2017). Corporate governance structure and capital adequacy: implications to bank risk taking. International Journal of Managerial Finance, 13(2), 165-185. https://doi.org/10.1108/IJMF-04-2016-0078

Acero, I., \& Alcade, N. (2012). The effect of the monitoring function and advisory function on board structure. Revista Espanola de Financiacion y Contabilidad, 41(153), 9-38. https://doi.org/10.1080/02102412.2012.10779717

Acharya, V. V., \& Richardson, M. (2009a). Causes of the financial crisis. Critical Review, 21(2-3), 195210. https://doi.org/10.1080/08913810902952903

Acharya, V. V., \& Richardson, M. (2009b). Restoring financial stability: how to repair a failed system. John Wiley \& Sons. https://doi.org/10.1002/9781118258163

Acharya, V. V., Schnabl, P., \& Suarez, G. (2009). Securitization without risk transfer (Working Paper). New York University Stern School of Business. https://doi.org/10.3386/w15730

Adams, R., \& Mehran, H. (2003). Is corporate governance different for bank holding companies? Economic Policy Review, 9, 123-142. https://doi.org/10.2139/ssrn.387561

Aebi, V., Sabato, G., \& Schmid, M. (2012). Risk management, corporate governance, and bank performance in the financial crisis. Journal of Banking \& Finance, 36(12), 3213-3226. https://doi.org/10.1016/j.jbankfin.2011.10.020

Alexander, K. (2006). Corporate governance and banks: The role of regulation in reducing the principal-agent problem. Journal of Banking Regulation, 7, 17-40. https://doi.org/10.1057/palgrave.jbr.2340003

Almășan, A., Circa, C., Dumitru, M., Gușe, R. G., \& Mangiuc, D. M. (2019). Effects of integrated reporting on corporate disclosure practices regarding the capitals and performance. Amfiteatru Economic, 21(52), 572-589. https://doi.org/10.24818/EA/2019/52/572

Avram, V., Calu, D. A., Dumitru, V. F., \& Dănescu, T. (2019). The clarity of the information regarding the bioeconomy: an analysis of the reports published by the organizations. Amfiteatru Economic, 21(50), 41-59. https://doi.org/10.24818/EA/2019/50/41

Banham, R. (2000, April). Kit and caboodle: understanding the skepticism about enterprise risk management. CFO Magazine.

Barber, B. M., \& Odean, T. (2001). Boys will be boys: Gender, overconfidence, and common stock investment. Quarterly Journal of Economics, 116, 261-292. https://doi.org/10.1162/003355301556400

Barker, V. L., \& Mueller, G. C. (2002). CEO characteristic and firm R\&D spending. Management Science, 48(1), 782-801. https://doi.org/10.1287/mnsc.48.6.782.187

Basel Committee on Banking Supervision. (2006). Core principles for effective banking supervision. https://www.bis.org/list/bcbs/spp_12/from_01012006/index.htm

Bebchuk, L. A., \& Spamann, H. (2010). Regulating bankers' pay. Georgetown Law Journal, 247. http://georgetownlawjournal.org/files/pdf/98-2/BebchukSpamann.PDF

Belenzon, S., Shamshur, A., \& Zarutskie, R. (2019). CEO's age and the performance of closely held firms. Strategic Management Journal, 40(6), 917-944. https://doi.org/10.1002/smj.3003

Beltratti, A., \& Stulz, R. M. (2011). The credit crisis around the globe: Why did some banks perform better? (Charles A. Dice Center Working Paper No. 2010-5; Fisher College of Business Working Paper No. 2010-03-005). https://doi.org/10.2139/ssrn.1572407 
Boitan, I., \& Niţescu, D. C. (2019). Does corporate governance support efficiency in banking business? Evidence from European Systemic banks. Journal of Economics, Slovak Academy of Sciences, 67(5), 525-549. https://www.sav.sk/journals/uploads/0712105605\%2019\%20Boitan\%20-\%20Nitescu\%20 + SR.pdf

Boone, A., Field, L. C., Karpoff, J. M., \& Raheja, C. G. (2007). The determinants of corporate board size and composition: an empirical analysis. Journal of Financial Economics (JFE), 85(1), 66-101. https://doi.org/10.1016/j.jineco.2006.05.004

Boone, C., Lokshin, B., Guenter, H., \& Belderbos, R. (2019). Top management team nationality diversity, corporate entrepreneurship, and innovation in multinational firms. Strategic Management Journal, 40(2), 277-302. https://doi.org/10.1002/smj.2976

Borlea, S., Achim, M. V., \& Mare, C. (2017). Board characteristics and firm performances in emerging economies. Lessons from Romania. Economic Research-Ekonomska Istraživanja, 30(1), 55-75. https://doi.org/10.1080/1331677X.2017.1291359

Brancato, C., Tonello, M., Hexter, E., \& Newman, K. R. (2009). The role of U.S. corporate boards in enterprise risk management. Paper presented at the Conference Board Research Report No. R-139006-RR. https://doi.org/10.2139/ssrn.941179

Bunea, M. (2014). Basel III impact on Romanian banking system performance. SEA-Practical Application of Science, 2(03), 397-403.

Bunea, M., \& Dinu, V. (2019). The BASEL III impact on the Romanian banks's solvency. Montenegrin Journal of Economics, 15(1), 189-198.

Bunea, M., Dobre, F., Popa, A., \& Sahlian, D. (2018). Risk management, corporate governance and financial performance of the banking system in Romania. Proceedings of the International Conference on Business Excellence, 12(1), 182-196. https://doi.org/10.2478/picbe-2018-0018

Bunea, M., Siminica, M., \& Turlea, C. (2015). The correlation between external audit and financial performance of banks from Romania. Amfiteatru Economic, 17(9), 1273-1288.

Carter, D. A., Simkins, B. J., \& Simpson, W. G. (2003). Corporate governance, board diversity, and firm value. Financial Review, 38, 33-53. https://doi.org/10.1111/1540-6288.00034

Cavaco, S., Challe, E., Crifo, P., Rebérioux, A., \& Roudaut, G. (2016). Board independence and operating performance: analysis on (French) company and individual data. Applied Economics, 48(52), 5093-5105. https://doi.org/10.1080/00036846.2016.1170936

Cebenoyan, A. S., \& Strahan, P. E. (2001). Risk management, capital structure and lending at banks. https://doi.org/10.2139/ssrn.293378

Crossland, C., \& Hambrick, D. C. (2011). Differences in managerial discretion across countries: How nation-level institutions affect the degree to which CEOs matter. Strategic Management Journal, 32(8), 797-819. https://doi.org/10.1002/smj.913

Cumming, C., \& Mirtle, B. (2001). The challenges of risk management in diversified financial institutions. Federal Reserve Bank of New York Economic Policy Review, 7, 1-17.

Diamond, D., \& Rajan, R. (2009). Fear of fire sales and the credit freeze (Working Paper). University of Chicago. https://doi.org/10.3386/w14925

Díaz, B., Ramos, R. G., \& Baraibar-Díez, E. (2017). Corporate governance in Europe: has the crisis affected corporate governance policies? In Responsible Corporate Governance (pp. 73-96). Springer International Publishing. https://doi.org/10.1007/978-3-319-55206-4_5

Dinu, V., \& Bunea, M. (2015). The relationship between the audit committee and the financial performance, the asset quality and the solvency of banks in Romania. Transformations in Business \& Economics, 14(2/35), 161-173.

Dinu, V., \& Bunea, M. (2018). The impact of the gender diversity on the romanian banking system performance. Transformations in Business \& Economics, 17(2/44), 42-59. 
Dutta, P., \& Bose, S. (2006). Gender diversity in the boardroom and financial performance of commercial banks: evidence from Bangladesh. The Cost and Management, 34(6), 70-74.

Ellul, A., \& Yerramilli, V. (2013). Stronger risk controls, lower risk: evidence from U.S. bank holding companies. Journal of Finance, 68(5), 1757-1803. https://doi.org/10.1111/jofi.12057

Erhardt, N. L., Werbel, J. D., \& Shrader, C. B. (2003). Board of director diversity and firm financial performance. Corporate Governance: An International Review, 11(2), 102-111. https://doi.org/10.1111/1467-8683.00011

Erkens, D. H., Hung, M., \& Matos, P. (2012). Corporate governance in the 2007-2008 financial crisis: Evidence from financial institutions worldwide. Journal of Corporate Finance, 18(2), 389-411. https://doi.org/10.1016/j.jcorpfin.2012.01.005

Fahlenbrach, R., \& Stulz, R. (2011). Bank CEO incentives and the credit crisis. Journal of Financial Economics, 99(1), 11-26. https://doi.org/10.1016/j.jfineco.2010.08.010

Farag, H., \& Mallin, C. (2017). Board diversity and financial fragility: Evidence from European banks. International Review of Financial Analysis, 49, 98-112. https://doi.org/10.1016/j.irfa.2016.12.002

Garcia-Marco, T., \& Robles-Fernandez, M. D. (2008). Risk-taking behaviour and ownership in the banking industry: The Spanish evidence. Journal of Economics and Business, 60(4), 332-354. https://doi.org/10.1016/j.jeconbus.2007.04.008

Gottesman, A. A., \& Morey, M. R. (2010). CEO educational background and firm financial performance. Journal of Applied Finance, 20(2). https://ssrn.com/abstract=2693079

Guerrera, F., \& Thal-Larsen, P. (2008, June 26). Gone by the board: why the directors of big banks failed to spot credit risks. Financial Times.

https://www.ft.com/content/6e66fe18-42e8-11dd-81d0-0000779fd2ac

Guest, P. (2009). The impact of board size on firm value: Evidence from the UK. European Journal of Finance, 15, 385-404. https://doi.org/10.1080/13518470802466121

Hambrick, D. C., \& Mason, P. A. (1984). Upper echelons: The organization as a reflection of its top managers. The Academy of Management Review, 9(2), 193-206. https://doi.org/10.2307/258434

Hashagen, J., Harman, N., Conover, M., \& Sharma, J. (2009). Risk management in banking: Beyond the credit crisis.Journal of Structured Finance, 15(1), 92-103. https://doi.org/10.3905/JSF.2009.15.1.092

Ioannou, I., \& Serafeim, G. (2012). What drives corporate social performance? The role of nation-level institutions. Journal of International Business Studies, 43(9), 834-864.

https://doi.org/10.1057/jibs.2012.26

Kirkpatrick, G. (2009). The corporate governance lessons from the financial crisis. OECD Journal: Financial Market Trends, 2009(1), 89-123. https://doi.org/10.1787/fmt-v2009-art3-en

Korent, D., Dunđek, I., \& Klačmer Čalopa, M. (2014). Corporate governance practices and firm performance measured by Croatian Corporate Governance Index (CCGI $\left.{ }^{\circ}\right)$. Economic Research-Ekonomska Istraživanja, 27(1), 221-231. https://doi.org/10.1080/1331677X.2014.952109

Lehn, K., Patro, S., \& Zhao, M. (2009). Determinants of the size and structure of corporate boards: 1935-2000. Financial Management, 38. https://doi.org/10.2139/ssrn.470675

Liang, Q., Xu, P., \& Jiraporn, P. (2013). Board characteristics and Chinese bank performance. Journal of Banking \& Finance, 37(8), 2953-2968. https://doi.org/10.1016/j.jbankfin.2013.04.018

Lu, J., Ren, L., He, Y., Lin, W., \& Streimikis, J. (2019). Linking corporate social responsibility with reputation and brand of the firm. Amfiteatru Economic, 21(51), 442-460.

https://doi.org/10.24818/EA/2019/51/422

Macey, J. R., \& O’Hara, M. (2003). The corporate governance of banks. Economic Policy Review, 9(1). https://ssrn.com/abstract $=795548$ 
Marinova, J., Plantenga, J., \& Remery, C. (2016). Gender diversity and firm performance: Evidence from Dutch and Danish boardrooms. The International Journal of Human Resource Management, 27(15), 1777-1790. https://doi.org/10.1080/09585192.2015.1079229

Mateos de Cabo, R., Gimeno, R., \& Escot, M. L. (2010). Disentangling discrimination on Spanish boards of directors. Corporate Governance: An International Review, 19(1), 77-95. https://doi.org/10.1111/j.1467-8683.2010.00837.x

Merton, R. (1977). The valuation of american put options. The Journal of Finance, 32(2), 449-462. https://doi.org/10.1111/j.1540-6261.1977.tb03284.x

Miccolis, J., \& Shaw, S. (2000). Enterprise risk management: an analytic approach. Tillinghast - Towers Perrin, New York.

Miller, K. D. (1992). A framework for integrated risk management in international business. Journal of International Business Studies, 23, 311-331. https://doi.org/10.1057/palgrave.jibs.8490270

Minton, B. A., Taillard, J., \& Rohan, W. G. (2011). Do independence and financial expertise of the board matter for risk taking and performance? (Fisher College of Business Working Paper Series). https://doi.org/10.2139/ssrn.1787126

Mintzberg, H. (2004). Managers not MBAs. A hard look at the soft practice of managing and management development. Berrett-Koehler Publishers. https://www.bkconnection.com/static/ Managers-Not-MBAs-EXCERPT.pdf

Mongiardino, A., \& Plath, C. (2010). Risk governance at large banks: Have any lessons been learned? Journal of Risk Management in Financial Institutions, 3(2), 116-123.

Murayev, A., Talavera, O., \& Wei, C. (2016). Performance effects of appointing other firms' executive directors to corporate boards: An analysis of UK firms. Review of Quantitative Finance and Accounting, 46, 25-45. https://doi.org/10.1007/s11156-014-0460-6

Negrei, C., \& Istudor, N. (2018). Circular economy - between theory and practice. Amfiteatru Economic, 20(48), 498-509. https://doi.org/10.24818/EA/2018/48/498

Niţescu, D. C., \& Boitan, I. A. (2017). Guvernanţa şi auditul intern în domeniul bancar. Editura ASE. https://editura.ase.ro/Carte/Guvernanta-si-auditul-intern-in-domeniul-bancar/

Nocco, B. W., \& Stulz, R. M. (2006). Enterprise risk management: theory and practice. Journal of Applied Corporate Finance, 18, 8-20. https://doi.org/10.1111/j.1745-6622.2006.00106.x

Pathan, S., \& Faff, R. (2013). Does board structure in banks really affect their performance? Journal of Banking \& Finance, 37(5), 1573-1589. https://doi.org/10.1016/j.jbankfin.2012.12.016

Pathan, S., \& Skully, M. T. (2010). Endogenously structured boards of directors in banks. Journal of Banking and Finance, 34(7), 1590-1606. https://doi.org/10.1016/j.jbankfin.2010.03.006

Raheja, C. G. (2005). Determinants of board size and composition: a theory of corporate boards. Journal of Financial and Quantitative Analysis, 40(2), 283-306. https://doi.org/10.1017/S0022109000002313

Sabato, G. (2010). Financial crisis: where did risk management fail? International Review of Applied Financial Issues and Economics, 2, 12-18. https://doi.org/10.2139/ssrn.1460762

Savoiu, G., Dinu, V., \& Tachiciu, L. (2012). Romania foreigen trade in global recession, revealed by the extended method of exchange rate indicators. Amfiteatru Economic, 14(31), 173-194.

Srivastav, A., \& Hagendorff, J. (2016). Corporate governance and bank risk-taking. Corporate Governance: An Interntional Review, 24(3), 334-345. https://doi.org/10.1111/corg.12133

Strebel, P. (2011). In touch boards: reaching out to the value critical stakeholders. Corporate Governance, 11(5), 603-610. https://doi.org/10.1108/14720701111177000

Stulz, R. M. (2016). Risk management, governance, culture, and risk taking in banks. Economic Policy Review, 8, 43-60. https://ssrn.com/abstract=2828073 
Terjesen, S., Couto, E. B., \& Francisco, P. M. (2016). Does the presence of independent and female directors impact firm performance? A multi-country study of board diversity. Journal of Management and Governance, 20(3), 447-483. https://doi.org/10.1007/s10997-014-9307-8

Van Greuning, H., \& Brajovic Bratanovic, S. (2003, December). Analyzing and managing banking risk: a framework for assessing corporate governance and financial risk management (2nd ed.). World Bank Publications, The World Bank. https://doi.org/10.1596/0-8213-5418-3

Vătămănescu, E.-M., Alexandru, V.-A., Cristea, G., Radu, L., \& Chirica, O. (2018). A demand-side perspective of bioeconomy: the influence of online intellectual capital on consumption. Amfiteatru Economic, 20(49), 536-552. https://doi.org/10.24818/EA/2018/49/536

Vuță, M., Cioacă, S. I., Vuţă, M., \& Enciu, A. (2019). An empirical analysis of corporate social responsibility effects on financial performance for Romanian listed companies. Amfiteatru Economic, 21(52), 607-622. https://doi.org/10.24818/EA/2019/52/607

Walker, D. (2009, July 16). A review of corporate governance in UK banks and other financial industry entities. Walker Review. 